\title{
Differential expression profiling of head and neck squamous cell carcinoma (HNSCC)
}

\author{
F Lemaire',4, R Millon 2,4, J Young 1,4, A Cromer', C Wasylyk', I Schultz², D Muller², P Marchal', C Zhao', \\ D Melle $^{3}$, L Bracco ${ }^{3}$, J Abecassis ${ }^{2}$ and B Wasylyk ${ }^{*, 1}$
}

'Institut de Génétique et de Biologie Moléculaire et Cellulaire, CNRS/INSERM/ULP, I Rue Laurent Fries, BP I 0142,67404 IIIkirch cedex, France; ${ }^{2}$ UPRES EA 34-30, Centre Paul Strauss, 3 rue de la Porte de l'Hôpital, 67085 Strasbourg, France; ${ }^{3}$ Exonhit Therapeutics, 65 Boulevard Masséna, Paris F-750 I3, France

Head and neck squamous cell carcinoma (HNSCC) is the fifth most common cancer in men with an incidence of about 780000 new cases per year worldwide and a poor rate of survival. There is a need for a better understanding of HNSCC, for the development of rational targeted interventions and to define new prognostic or diagnostic markers. To address these needs, we performed a largescale differential display comparison of hypopharyngeal HNSCCs against histologically normal tissue from the same patients. We have identified 70 genes that exhibit a striking difference in expression between tumours and normal tissues. There is only a limited overlap with other HNSCC gene expression studies that have used other techniques and more heterogeneous tumour samples. Our results provide new insights into the understanding of HNSCC. At the genome level, a series of differentially expressed genes cluster at $|2 p| 2-13$ and |q2|, two hotspots of genome disruption. The known genes share functional relationships in keratinocyte differentiation, angiogenesis, immunology, detoxification, and cell surface receptors. Of particular interest are the 13 'unknown' genes that exist only in EST, theoretical CDNA and protein databases, or as chromosomal locations. The differentially expressed genes that we have identified are potential new markers and therapeutic targets.

British Journal of Cancer (2003) 89, 1940- 1949. doi:1 0.1038/sj.bjc.660 I 373 www.bjcancer.com

(c) 2003 Cancer Research UK

Keywords: hypopharynx; 'unknown' genes; functional classes; biomarkers; pharmaceutical targets; virtual Northern

Head and neck squamous cell carcinoma (HNSCC) arises from the surface epithelium of the upper-aerodigestive tract (pharynx, hypopharynx, and larynx) and the oral cavity. Extensive epidemiological studies show that alcohol potentiates tobacco-related carcinogenesis and is also an independent risk factor. Head and neck squamous cell carcinoma is the fifth most common cancer in men with an incidence of about 780000 new cases per year worldwide (Sankaranarayanan et al, 1998). Surgery and radiotherapy are highly effective in the treatment of stage I and II tumours, but over $70 \%$ of patients present with locoregionally advanced stage III or IV disease. Locoregional disease recurs in $60 \%$ of patients and metastatic disease develops in $15-25 \%$ (Genden et al, 2003). Furthermore, patients develop second primary tumours at an annual rate of 3-7\% (Leon et al, 2002). However, less than $30 \%$ of HNSCC patients are free of disease after 3 years, and 5-year survival rates have remained largely unchanged in the last three decades (Dimery and Hong, 1993). The characterisation of the molecular determinants of the head and neck carcinogenesis process is essential for the better understanding of this malignancy and the development of rational targeted intervention.

\footnotetext{
*Correspondence: Dr B Wasylyk; E-mail: boh@igbmc.u-strasbg.fr.

${ }^{4}$ These authors contributed equally to this manuscript and are listed alphabetically.

Received I5 May 2003; revised 9 September 2003; accepted 16 September 2003
}

Specific genes have been associated with the development or presentation of HNSCC, but these individual alterations have failed to define prognostic or diagnostic markers (reviewed in Leonard et al (1991) and Scully et al (2000)). Addressing this issue requires large-scale analysis of gene expression profiles. A number of recent studies have reported gene expression profiles of small numbers of HNSCC patients using commercial or focused microarrays (Leethanakul et al, 2000; Xie et al, 2000; Alevizos et al, 2001; Al Moustafa et al, 2002; Belbin et al, 2002; El-Naggar et al, 2002; Mendez et al, 2002). The microarray analysis is limited by the set of genes on the arrays, whereas polymerase chain reaction differential display (PCR-DD) randomly samples the transcriptome. The PCR-DD has been used to discover novel genes that would not have been identified using methodologies that cover a predefined range of genes (Glynne-Jones et al, 2001; Sasaki et al, 2001; Ying et al, 2001). We have performed the first randomised comparative analysis of gene expression of HNSCC patients using PCR-DD. We did not use microdissected tumour or normal components for this analysis since numerous studies have shown that the host tumour microenvironment influences tumour cells (van den Hooff, 1988; Nelson et al, 2000; Coussens et al, 1999; St Croix et al, 2000). We have identified a series of novel genes that exhibit striking differences in expression between HNSCC tumours and histologically normal matched tissues. They should contribute to a better understanding of HNSCC and provide new targets for therapeutics. 


\section{MATERIALS AND METHODS}

\section{Samples}

Hypopharyngeal tumours and the corresponding histologically normal tissue, used with consent, were derived from surgical resections of squamous cell carcinoma. The patients had not been treated at the time of surgery, but were subsequently treated with radiotherapy. The samples used were resected near the advancing edge of the tumours avoiding their necrotic centres. They were comprised of $70-80 \%$ cancer cells in almost all cases, as assessed on adjacent histological stained sections. Normal samples were collected from the farthest margin of the surgical resections (usually uvula). The tumours were classified according to TNM stages (tumour, node, metastasis) based on the UICC criteria (Sobin and Wittekind, 1997), and grouped into three categories. The early (E) stage corresponds to small-sized tumours (T1/T2), moderately to well differentiated, without lymph node involvement. The two later-stage tumour types were of medium size (T2/ T3), homogeneous differentiation and lymph node involvement $(\mathrm{N} 1-\mathrm{N} 2 \mathrm{c})$. At the time of resection, these later-stage tumours appeared clinically and histologically similar. However, during 3year follow-up, one group of patients did not develop metastases (no metastatic propensity: NM), whereas the other developed metastases predominantly in the lung, bone, and liver (with metastatic propensity: $M$ ).

\section{PCR-Differential display}

Total RNA was isolated with RNAeasy (Qiagen, Courtaboef, France), DNAseI treated, column purified (Qiagen) and pooled according to the tumour type (3 E, $2 \mathrm{NM}$ and $2 \mathrm{M}$ patients). The corresponding normal RNAs were similarly pooled. The PCR-DD was performed on the pooled samples using $585^{\prime}$ primers (HAP) in combination with three $3^{\prime}$ primers (HT11A/G/C) according to the GenHunter protocol and as described by Liang et al (Liang, 1998). All samples were prepared in duplicate from the reverse transcription stage to reduce experimental variability. Differential bands were isolated, reamplified with the corresponding primers, verified by agarose gel electrophoresis, and cloned in the pGEMt-Easy vector (Promega, Charbonnères, France). Eight colonies per band were expanded in liquid culture. A volume of $2 \mu \mathrm{l}$ of the cultures were used for PCR, in the same conditions as the reamplification, with the pGEME1 and pGEME2 primers ( $5^{\prime}$-CGC GGT ACC GGA TCC ATG CAT TGG CGG CCG CGG GAA TTC-3' and 5'-CGC GGT ACC GGA TCC ATG CAT CAT ATG GTC GAC CTG CAG- ${ }^{\prime}$, respectively). The fragments (50-800 base pairs) were verified by agarose gel electrophoresis, and subsequently the DNA was spotted directly onto nitrocellulose membranes (Hybond $\mathrm{N}+$, Amersham, Les Ulis, France) using a 96well vacuum-driven dot blot manifold (Bio-Rad, Marnes-la-Coquette, France). Filters underwent denaturation $(1.5 \mathrm{M} \mathrm{NaCl}, 0.5 \mathrm{M}$ $\mathrm{NaOH})$ and neutralisation $(1.5 \mathrm{M} \mathrm{NaCl}, 0.5 \mathrm{M}$ Tris- $\mathrm{HCl} \mathrm{pH} \mathrm{7.2,}$ 0.001 м EDTA) followed by UV cross-linking.

Table I Real-time quantitative PCR primers and reaction conditions.

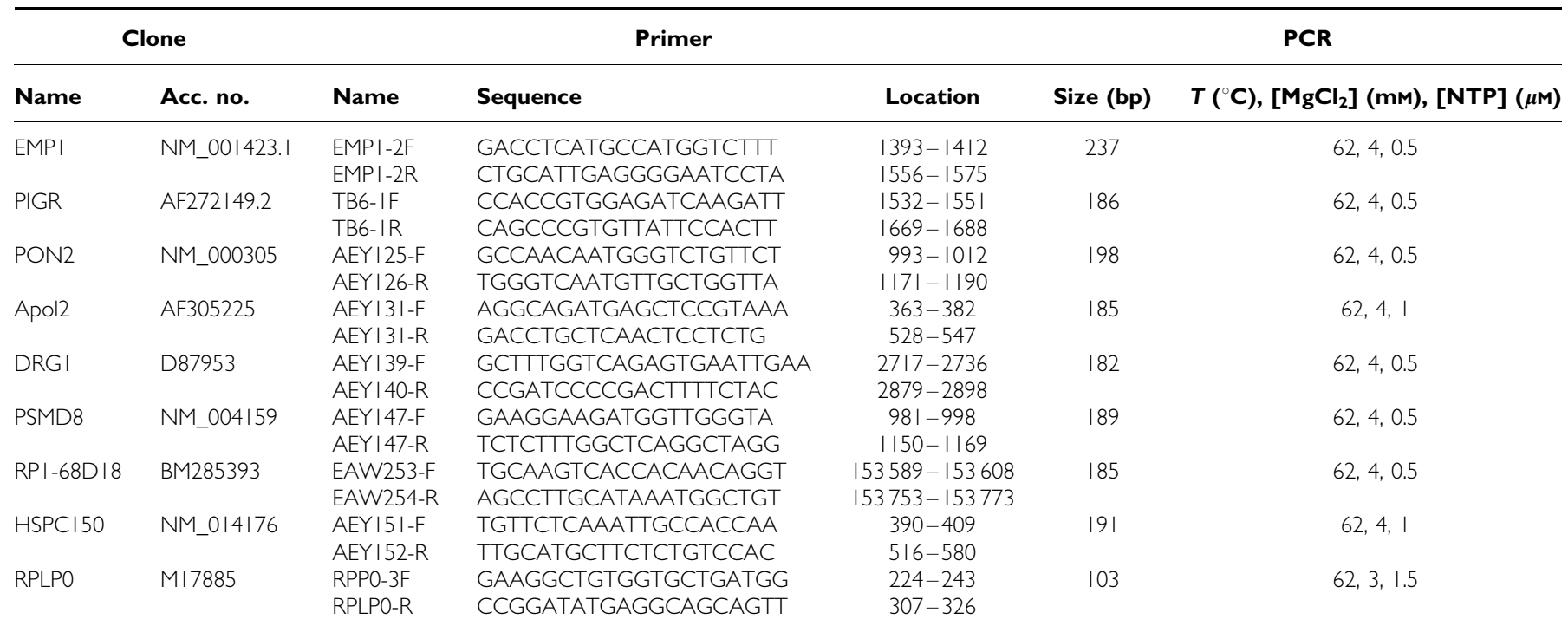

Listed above are the clone names and accession numbers; the primer name, sequence $\left(5^{\prime}-3^{\prime}\right)$ and location on the sequence associated with the accession number; and the PCR product size and reaction conditions (annealing temperature and concentrations of $\mathrm{MgCl}_{2}$ and NTP).

Table 2 Characteristics of the tumours

\begin{tabular}{|c|c|c|c|c|c|c|c|c|c|c|c|c|}
\hline I & $E$ & 2 & 0 & 0 & 2 & $M$ & 53 & $R X$ & 0 & 11 & 15 & D \\
\hline 3 & $E$ & 2 & 0 & 0 & 2 & $M$ & 44 & $N$ & 0 & 41 & 41 & $A$ \\
\hline 4 & NM & 3 & $2 b$ & 0 & 3 & $M$ & 66 & $R X$ & 0 & 54 & 58 & D \\
\hline 5 & NM & 3 & $2 b$ & 0 & 2 & $M$ & 52 & $R X$ & SC & 39 & 44 & A \\
\hline 6 & $M$ & 2 & $2 c$ & 0 & 3 & $M$ & 54 & $R X$ & $M$ & 16 & 25 & D \\
\hline
\end{tabular}

All the tumours were localised in the hypopharynx. T, N, and M correspond to the TNM nomenclature for tumour stage (tumour, node, and metastasis). Diff (differentiation): $\mathrm{I}=$ well, $2=$ moderate, $3=$ poorly. Treatment after surgery: $\mathrm{RX}=$ radiotherapy; $\mathrm{N}=$ no treatment. Evolution: $0=$ no evolution, $\mathrm{M}=$ metastasis, $\mathrm{SC}=$ secondary cancer. Actual state: $D=$ dead, $A=$ alive 


\section{Reverse Northerns}

Owing to the limiting quantity of patient RNA, the SMART cDNA synthesis system (Clontech, Lee Pont de Claix, France) was used to reverse transcribe and amplify total RNA to be used as a probe. The first strand, synthesised from $0.2 \mu \mathrm{g}$ of total RNA, was amplified for a controlled number of cycles, to ensure linearity, as described by the manufacturer. The labelling was performed with $100 \mathrm{ng}$ of SMART CDNA and a mix of the DD primers that originally generated the clones. The probes were purified through Sephadex G50 columns (Bio-Rad). The filters were hybridised in $10 \%$ dextran sulphate $/ 0.1 \%$ SDS $/ 10 \mathrm{~mm} \mathrm{NaCl}$ overnight at $65^{\circ} \mathrm{C}$, washed to a stringency of $0.2 \times \mathrm{SSC} / 0.1 \%$ SDS at $65^{\circ} \mathrm{C}$ and exposed on Biomax film for $3-24 \mathrm{~h}$ at $-80^{\circ} \mathrm{C}$, and subsequently on Molecular Dynamics PhosphorImager screens (Orsay, France) for quantification on a Typhoon PhosphorImager analyser (Orsay, France). Positive clones were then expanded from the original liquid cultures and plasmid DNA extracted using standard alkaline lysis followed by purification through Nucleospin miniprep columns (Macherey-Nagel, Hoebdt, France). The sequences of

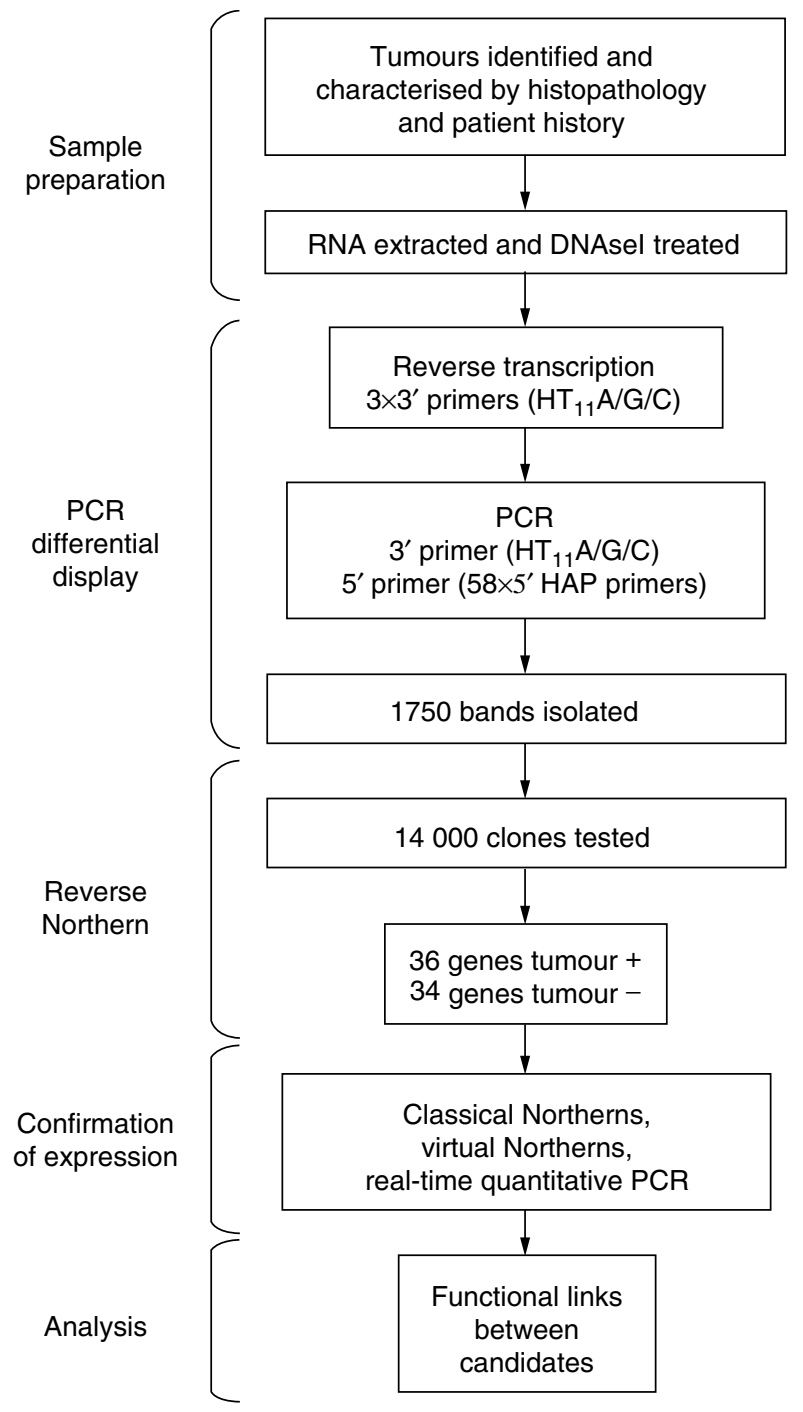

Figure I Flowchart outlining the study. The flowchart indicates how the tumour samples were selected and processed, the PCR-DD primers that were used and the number of bands isolated, the number of clones tested by reverse Northern, the resulting number of genes identified, the types of confirmation used to validate the results, and the bioinformatics analysis to analyse the results. the inserts were analysed with the BLAST algorithm at http:// www.ncbi.nlm.nih.gov/blast/. Positive clones were then confirmed at least twice with probes generated (as above) from two independent SMART cDNA preparations. The filters included control positive clones that were systematically used for cross comparison.

\section{Classical Northerns}

Total RNA was extracted from tissue samples with Trizol (Life Technologies, Cergy Pontoise, France). A measure of $20 \mu \mathrm{g}$ of RNA was subjected to agarose $/ 6 \%$ formaldehyde gel electrophoresis, then transferred to Hybond $\mathrm{N}+$ membranes (Amersham). $\left[{ }^{32} \mathrm{P}\right]-$ labelled probes were generated with the Rediprime system (Amersham). Membranes were prehybridised and hybridised in $50 \%$ formamide at $42^{\circ} \mathrm{C}$ according to the manufacturer's

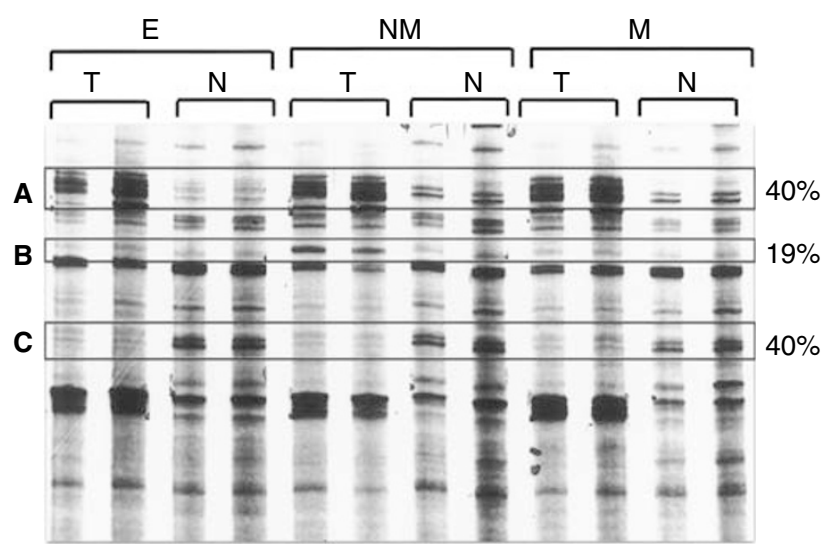

Figure 2 Differential display gel comparing the three stages of tumours $(T)$ with their corresponding normal $(N)$ samples. $E=$ early; $N M=n o$ metastatic potential; $M=$ metastatic propensity. Highlighted are the three types of profiles (A overexpressed in tumour; $\mathbf{B}$, tumour-specific profiles; C. underexpressed in tumour), and the percentages give the overall proportions in these categories.

A

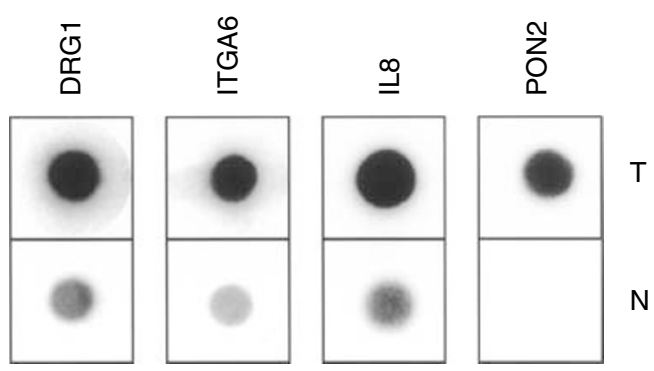

B

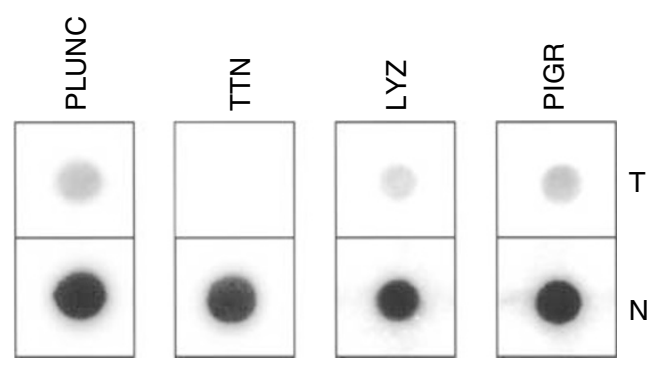

Figure 3 Reverse Northerns using tumour $(T)$ or normal $(N)$ tissue probes. The genes shown, which are overexpressed $(\mathbf{A})$ or underexpressed (B) in tumours, are the first four in Tables $3 A$ and $B$, respectively. 
Table 3 Differentially expressed genes identified by PCR differential display (PCR-DD) and reverse Northern analysis in Parts A and B

\begin{tabular}{|c|c|c|c|c|c|}
\hline Order & Clone & Gene & Chromosome & Unigene or acc. no. & Immune \\
\hline \multirow{26}{*}{ N } & $\mathrm{B} 13.4$ & DRGI, N-myc downstream regulated gene I & $8 \mathrm{q} 24.3$ & Hs.75789 & \\
\hline & $100 \mathrm{~b} 82$ & PON2, paraoxonase 2 & $7 q 21.3$ & Hs. 169857 & \\
\hline & $2 b \mid l$ & HPRT, hypoxanthine phosphoribosyltransferase & $\times q 26-q 27.2$ & Hs.82314 & \\
\hline & $x 017.6$ & Immunoglobin kappa $L$ chain constant region gene & $2 \mathrm{p} 12$ & NG_000834 & Related \\
\hline & $183 \mathrm{H}$ & APOBEC 3 , apolipoprotein B mRNA editing enzyme & $22 \mathrm{q} 13.1$ & AL03/856 & \\
\hline & $22 \mid G$ & APTX, aprataxin & $9 p / 3.3$ & Hs. 14394 & \\
\hline & 01.7 & Chr 5, clone CTC-202FIO & $5 q 35$ & ACO10216 & \\
\hline & I07E & PLA2G7, phospholipase A2, group VII & $6 \mathrm{p} 21.2-\mathrm{p} 12$ & Hs. 93304 & Related \\
\hline & $108 \mathrm{~A}$ & Clone RPI I-367F23, chromosome 9 & $9 \mathrm{q} 22.31$ & AL355607 & \\
\hline & $120 \mathrm{~b} \mid 45$ & APOL2, apolipoprotein L, 2 & $22 q 12$ & Hs.241412 & \\
\hline & A74j5 & RPL27, ribosomal protein L27 & $17 q 21.1-q 21.2$ & Hs.l]161I & \\
\hline & $\mathrm{B} \mid 4.3$ & Chr 18, clone RPII-650PI5 & $|8 q| 1$ & $\mathrm{ACO} 21549$ & \\
\hline & $29 \mid \mathrm{D}$ & EFNB2, ephrin-B2 & $13 q 33$ & Hs.30942 & \\
\hline & $99 \mathrm{ci} 2$ & Chrl6, clone RPII-170L3 & $|6 p| 1.1$ & AC034105 & \\
\hline & P2.8 & SPOCK, testican I & $5 q 31$ & Hs.93029 & \\
\hline & $31+50$ & PSMB8, proteasome subunit, beta type 8 & $6 \mathrm{p} 21.3$ & Hs. 180062 & \\
\hline & $09 \overline{5} 4 \mathrm{~B}$ & IFIT2, interferon-induced protein with tetratricopeptide repeats 2 & $10 q 23.33$ & XM_084477 & Related \\
\hline & $\mathrm{XB} 2 \mathrm{v} \cdot 2$ & TRAI, tumour rejection antigen (gp96) I & $12 q 24.2-q 24.3$ & Hs. 82689 & Related \\
\hline & $31 c$ & LTBP I, latent transforming growth factor beta binding protein I & $2 p 12-q 22$ & Hs.24I257 & \\
\hline & A8015 & ND 10 , nuclear domain 10 & $17 q 23.2$ & Hs. I54230 & \\
\hline & A75al & HMGA2, high mobility group AT-hook 2 & $12 q 15$ & Hs.2726 & \\
\hline & A7/ d 8 & MTND4, NADH dehydrogenase 4 & Mitochondrion & NC_001807 & \\
\hline & C66p4 & DIAI, diaphorase (NADH) (cytochrome b-5 reductase) & $22 \mathrm{q}|2.3|-\mathrm{qter}$ & $\mathrm{Hs} .80706$ & \\
\hline & C68bl & Stat I, signal transducer and activator of transcription I & $2 q 32.2-q 32.3$ & Hs.21486 & Related \\
\hline & $\mathrm{C} 78 \mathrm{gl}$ & RPL6, ribosomal protein $L 6$ & $12 q 23-24.1$ & Hs.349961 & \\
\hline & A7li & TDG, thymine-DNA glycosylase & $12 \mathrm{q} 24.1$ & Hs. 173824 & \\
\hline & G75el & SPRR3, small proline-rich protein 3 & $\mid q 21-q 22$ & Hs. 139322 & \\
\hline & $\mathrm{XH} 7.7$ & Similar to olfactory receptor MOR265-I & $12 q 12$ & $\times 87825$ & \\
\hline & $X\llcorner 6.3$ & CAPN7, calpain like protease 7 & $3 p 24$ & $\mathrm{Hs} .7145$ & \\
\hline & $\mathrm{C} 78 \mathrm{c} 8$ & CLECSF2, C-type lectin superfamily member 2 & $|2 p| 3-p \mid 2$ & Hs.8520l & Related \\
\hline & XKId.3 & MTND2, NAD́H dehydrogenase subunit 2 & Mitochondrion & NC_001807 & \\
\hline & $\mathrm{XH} 3.2$ & CILP, cartilage intermediate layer protein & $15 q 22$ & Hs. 151407 & Related \\
\hline & $|2| a \mid 49$ & Similar to common salivary protein I mRNA & $|6 p| 3.3$ & NM 145252 & \\
\hline & 1370 & PRH, proline-rich protein Haell & $|2 p| 3.2$ & Hs.73952 & \\
\hline & $x \mid 10.4$ & KIFI3B, kinesin family member I3B (gakin) & $8 \mathrm{p} / 2$ & Hs.1571I & \\
\hline & $A 77 \mathrm{~s} 8$ & KRTI3, cytokeratin 13 & $17 q 21-q 23$ & Hs.74070 & \\
\hline & $\mathrm{XH} 3.8$ & ARPP-19, phosphoprotein 19 & $|5 q| 5.3$ & Hs.735I & \\
\hline & LI.4 & Clone RPI3-253K9 on chromosome $\mathrm{X}$ & $x$ & AK024673 & \\
\hline & B7.4 & PER3, period homolog 3 & Ip36.23 & Hs. 12592 & \\
\hline & N6.8 & Chrl I, clone RPII-630PI (hypoprotein) & $1 / q$ & AP002774.3 & \\
\hline & 11.7 & KIAAOI 38 gene product & $19 p \mid 3.3$ & Hs. I59384 & \\
\hline & $\mathrm{XL9b.8}$ & Chromosome 12 clone RPI I-272BI7 & $12 q 13$ & AC06776 & \\
\hline & $38 \mathrm{~b} 17$ & CLIC4, chloride intracellular channel 4 & $|p 36.1|$ & Hs.25035 & \\
\hline & $\mathrm{XB} 6.4$ & KLK-L4, kallikrein-like protein 4 gene & $|9 q| 9.3-q \mid 9.4$ & Hs. 165296 & Related \\
\hline & $X\llcorner 6.2$ & KIAAI32I gene product & $|7 q| 1 . \mid$ & Hs.24336 & \\
\hline & XL9b. I & LTF, lactotransferrin & $3 q 21-q 23$ & Hs. 105938 & \\
\hline & 135B & EGLN2, EGL9 homolog & $19 \mathrm{q} \mid 3.2$ & Hs.324277 & \\
\hline & $\mathrm{C} 68 \mathrm{a} 4$ & GCLC, glutamate-cysteine ligase, catalytic subunit & $6 \mathrm{p} 12$ & Hs. 151393 & \\
\hline & A77e2 & SPRR2, small proline-rich protein 2 & $|\mathrm{q} 2|$ & Hs.355542 & \\
\hline & G80d5 & EMPI, epithelial membrane protein I & $|2 p| 2.3$ & Hs.79368 & \\
\hline & $\mathrm{G} 72 \mathrm{hl}$ & S $100 A 9$, S 100 calcium binding protein A9 & $|q 2|$ & Hs. I 2405 & Related \\
\hline & $\mathrm{G} 74 \mathrm{Cl}$ & Hypothetical protein DKFZp76/Cl69 & $5 q 11.2$ & $\mathrm{Hs} .7 \mid 252$ & \\
\hline & $\mathrm{G} 78 \mathrm{a} 5$ & GJB2, gap junction protein, beta $2,26 \mathrm{kDa}$ & $|3 q||-q| 2$ & Hs.323733 & \\
\hline
\end{tabular}

The genes are listed in the order of the differences in expression levels. Also listed for each PCR-DD clone are the name of the clone, the corresponding gene name, chromosomal localisation, Unigene or accession number, and whether its function is related directly or indirectly with the immune response. 
specifications, washed to a stringency of $0.1 \times$ SSPE/0.1\% SDS at $50^{\circ} \mathrm{C}$ and exposed to X-ray film (Kodak, Les Ulis, France). The level of expression in tumour samples was analysed in comparison with the matched normal tissues after correction for loading using RPLO. Ribosomal phosphoprotein P0 (RPLP0, originally called 36B4) is a ubiquitous expressed gene that has been routinely used in different laboratories as an internal control to normalise for the amount of RNA. In a large study (98 cases), we confirmed by realtime quantitative PCR (RT-QPCR) that its expression level remains relatively constant between HNSCC tumours and matched normal tissues (data not shown). RPLP0 gave better results than the commonly used control GAPDH, which was more variable between samples in our experiments.

\section{Virtual Northerns}

A measure of $0.2 \mu \mathrm{g}$ of total RNA from individual patients was converted into SMART cDNA ((Franz et al, 1999) and the Clontech protocol). The optimal number of cycles for each sample was determined according to the manufacturer's instructions. Aliquots of the PCR products, after different numbers of cycles (15-25), were analysed by agarose gel electrophoresis and Northern blotting with RPLP0 as the probe. The amplification and the fidelity are considered to be optimum when the PCR is in the exponential phase of amplification, one or two cycles before reaching the plateau (range 17-20 cycles). The RPLP0 signal of the optimum PCR was used as an internal standard to equilibrate loading of the virtual Northerns. Appropriate amounts of this 'SMART' cDNAs were electrophoresed on agarose gels, transferred to Amersham Hybond $\mathrm{N}+$ nylon filters. Probes were labelled with $\left[{ }^{32} \mathrm{P}\right] \mathrm{dCTP}$ by random priming or PCR with the PGEME1 and pGEME2 primers (see above). Filters were hybridised in dextran sulphate (as above), exposed overnight to PhosphorImager screens and quantified using the Typhoon ImageQuant software. Filters were finally reprobed with RPLP0 to verify equal loading.

\section{Real-time quantitative PCR}

RNA was quantitated with the LightCycler system (Roche Diagnostics, Meylan, France). A measure of $1 \mu \mathrm{g}$ of total RNA was reverse transcribed with random primers and the Superscript II RT - PCR system (Life Technologies). The PCR reactions were performed with the LC Fast start DNA master SYBR green I reaction mixture according to the manufacturer's instructions. Volumes of $2 \mu \mathrm{l}$ of $1: 50$ diluted RT products were used in $20 \mu \mathrm{l}$ reactions. The nucleotide sequences of the primers and their localisations are shown in Table 1. The primers were chosen with the Primer3 software and their specificity was verified by BLAST analysis on the $\mathrm{nr}$ database (non redundant set of GenBank, EMBL, and DDJB databases). For each gene, a standard curve was constructed using serial dilutions of a single standard cDNA (equivalent to 100, 40, 20, $10,4,2$, and $1 \mathrm{ng}$ of total RNA) derived from a pool of 10 hypopharyngeal tumours. The concentrations of primers, $\mathrm{MgCl}_{2}$, probes, and cDNA were optimised to obtain linear standard curves. Unknown samples were estimated relative to these standard curves. For genes overexpressed in tumours, expression levels were calculated relative to the median values for normal tissue, and vice versa for genes expressed at higher levels in normal tissues. PCR reactions were run at least twice for each sample. The mean value was retained whenever the standard deviation did not exceed $15 \%$, and normalised using RPLP0 as an internal control.

\section{RESULTS}

\section{PCR differential display}

A large-scale PCR-DD was performed on patient RNA derived from three stages of HNSCC (Table 2) and corresponding normal tissues (see Figure 1 for a methodology outline). Three $3^{\prime}$ primers (HT11A/G/C) and $585^{\prime}$ primers (HAP1-10, 33-80) were combined to cover theoretically over $90 \%$ of expressed sequences (Liang, 1998). This experimental design maximises the detection of 'novel' sequences, a strength of PCR-DD compared to DNA arrays. Around $95 \%$ of the bands showed no difference in signal intensity across the different samples, as expected. Of the 1750 bands that
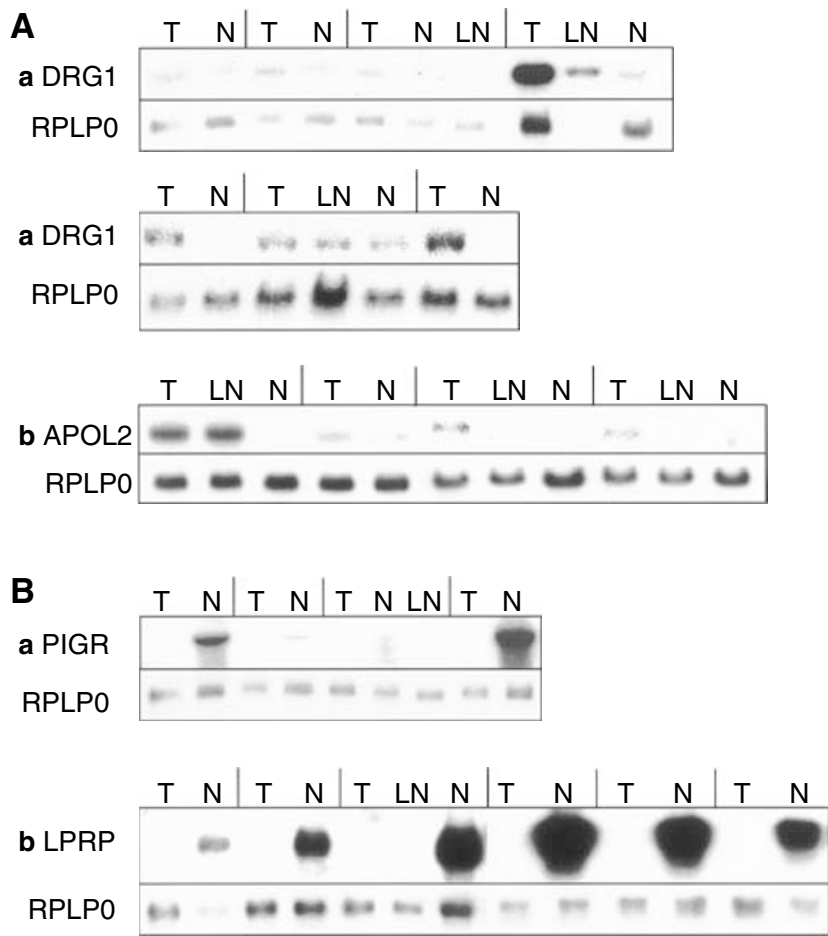

Figure 4 Classical Northerns: tumour ( $T$ ), lymph node ( $L N)$ and normal (N) samples from the same patients were analysed. The RPLPO control is shown under each lane. (A) Genes overexpressed in tumours: (a) DRGI, (b) APOL2. (B) Genes underexpressed in tumours: (a) PIGR, (b) LPRP. The lines separate the samples from particular patients, and comparisons should be made between the samples from each patient.

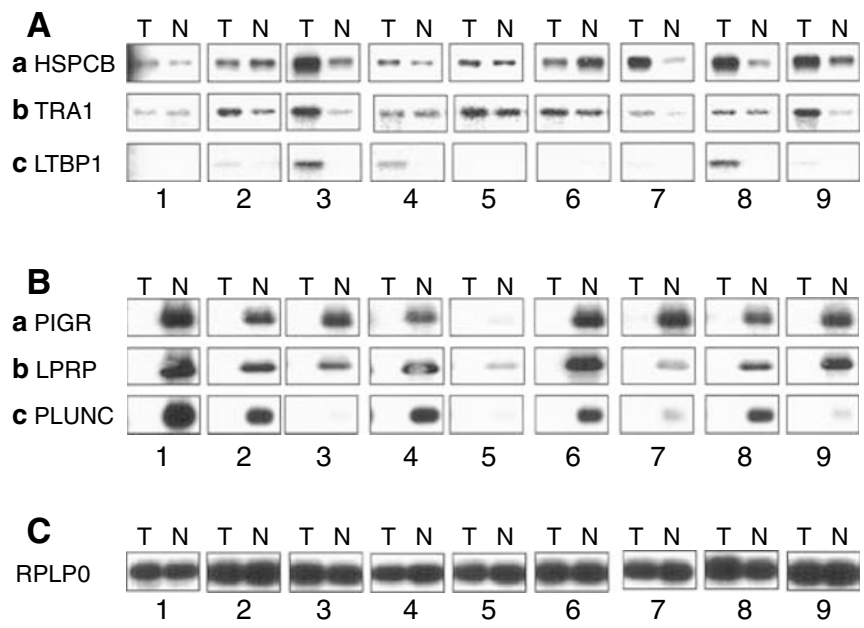

Figure 5 Virtual Northerns: the lanes $I-3$ (E), 6,7 (NM) and 8,9 correspond to individual patients who were pooled for the PCR-DD Tumour ( $\mathrm{T}$ ) and normal ( $\mathrm{N}$ ) samples from the same patient were compared. (A) Genes overexpressed in tumours: (a) HSPCB, (b) TRAI, and (c) LTBPI. (B) Genes underexpressed in tumours: (a) PIGR, (b) LPRP, and (c) PLUNC. (C) RPLPO is the internal control. 
did show a difference, $40 \%$ were increased and another $40 \%$ were diminished in all the tumour samples (Figure 2). These two groups are the focus of this initial study. The $19 \%$ of the bands that differed between the tumour types will be addressed in future studies. Less than $1 \%$ of the bands differed in intensity between the normal samples from different patients, indicating that the differences observed between the normal and tumour samples were due specifically to the development of the tumours and not due to either patient polymorphism or PCR-derived artefacts (Figure 2). The differential bands were isolated and cloned, and eight clones were taken from each band for further analysis.

\section{Identification of the genes}

Reverse Northern hybridisation (Zhang et al, 1997; Trenkle et al, 1999) was performed on the 14000 clones resulting from the DD to determine which clones among the eight clones derived from each band contained differentially expressed sequences. Macroarrays of the clones were hybridised with probes derived from either pooled tumour or pooled normal RNA, and the resulting signals were quantified. In total, 2500 clones presenting a tumour/normal signal ratio of $>2.0$ or $<0.5$ were grouped onto secondary arrays and reprobed twice for confirmation (Figure 3). Clones with consistently differential profiles after multiple hybridisations and tumour/normal ratio of $>2.0(2-5$-fold $)$ or $<0.5$ (0.5-0.07-fold) were sequenced and identified using the BLAST algorithm. Some of the clones with consistent profiles corresponded to the same gene (1-85 clones per gene). Our final list contains 36 genes that are overexpressed in tumours (Table $3 \mathrm{~A}$ ) and 34 genes that are under expressed (Table 3B). Six of the overexpressed and seven of the underexpressed sequences are novel, in that they do not correspond to known genes.

\section{Validation of gene expression profiles}

To confirm that the large-scale analysis had correctly identified differentially expressed sequences, some up- and downregulated genes were analysed by the classical Northern analysis (Figure 4). As the amount of patient material was too limited to do numerous classical Northerns, SMART technology (Clontech) was used to generate virtual Northerns (Figure 5). In addition, RT-QPCR was used with a panel of 14 hypopharyngeal carcinomas and matched normal tissues (Figure 6). The results were consistent across these validation techniques (DRG1, Figures 4Aa and 6Aa; APOL2, Figures $4 \mathrm{Ab}$ and $6 \mathrm{Ab}$; PIGR, Figures $4 \mathrm{Ba}, 5 \mathrm{Ba}$, and $6 \mathrm{Ba}$; LPRP, Figures $4 \mathrm{Bb}$ and $5 \mathrm{Bb}$; note that the patients were different). We found that PIGR, LPRP, PLUNC, and EMP1 are downregulated in almost all the tumours (Figures 4B, 5B, and 6B). DRG1, APOL2, HSPCB, TRA1, LTBP1, PON2, HSPC150, PSMB8, and clone RP1$68 \mathrm{D} 18$ are overexpressed in tumours at various frequencies
A
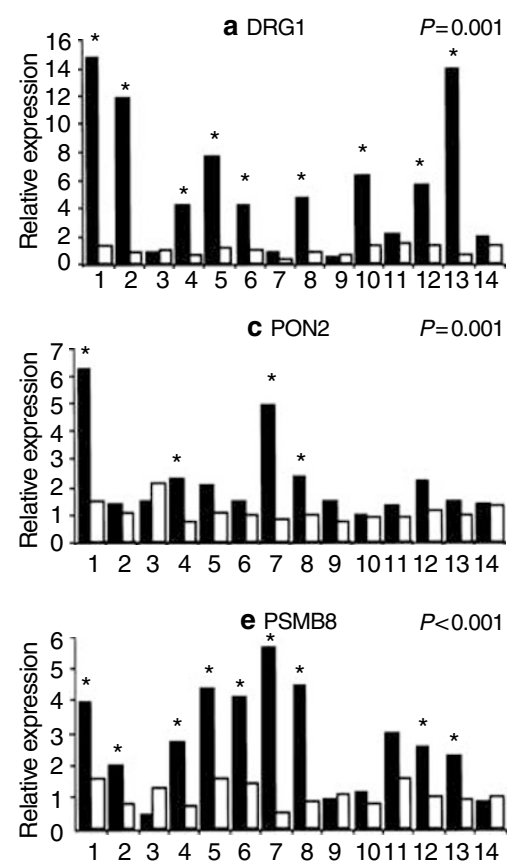

B

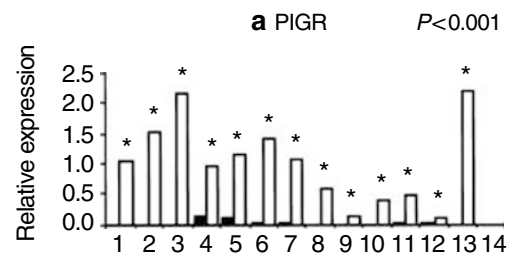

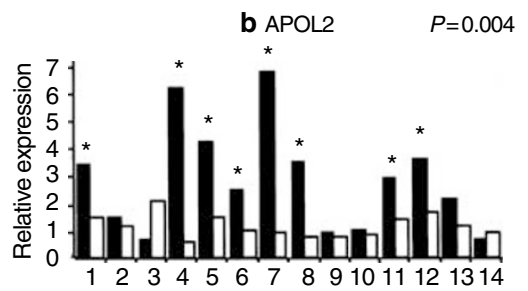
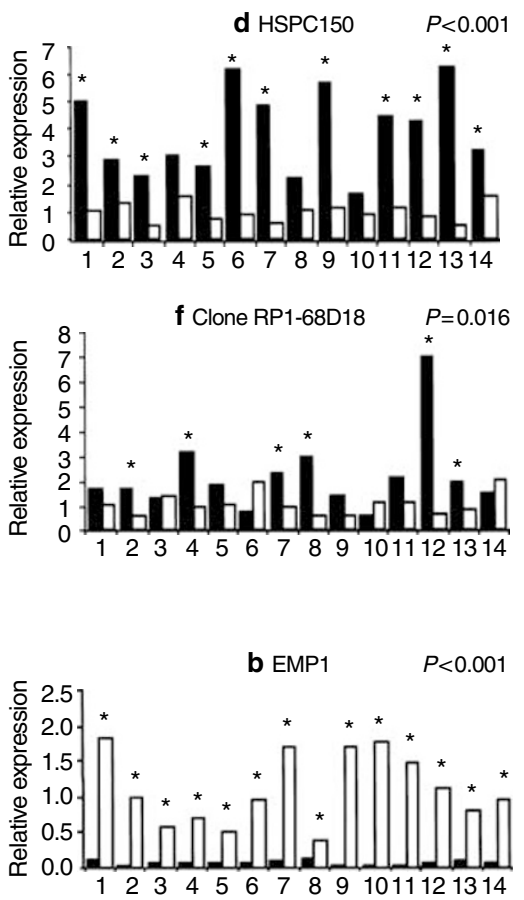

Figure 6 Real-time quantitative PCR. (A) Genes overexpressed in tumours (T): (a) DRGI, (b) APOL2, (c) PON2, (d) HSPCI 50, (e) PSMB8, and (f) RPI68D 18. (B) Genes underexpressed in tumours: (a) PIGR and (b) EMPI. The values for the tumours (black columns) and matched normal (N) tissue (white columns) were adjusted according to RPLPO, the internal control. The median of the $\mathrm{N}$ values was set to I. The patients indicated with a star have a matched $\mathrm{T} / \mathrm{N}$ ratio greater or equal to 2 . The $P$-values of $t$-tests between the tumour and normal tissues are indicated. 
Table 4 Comparison with other tumours

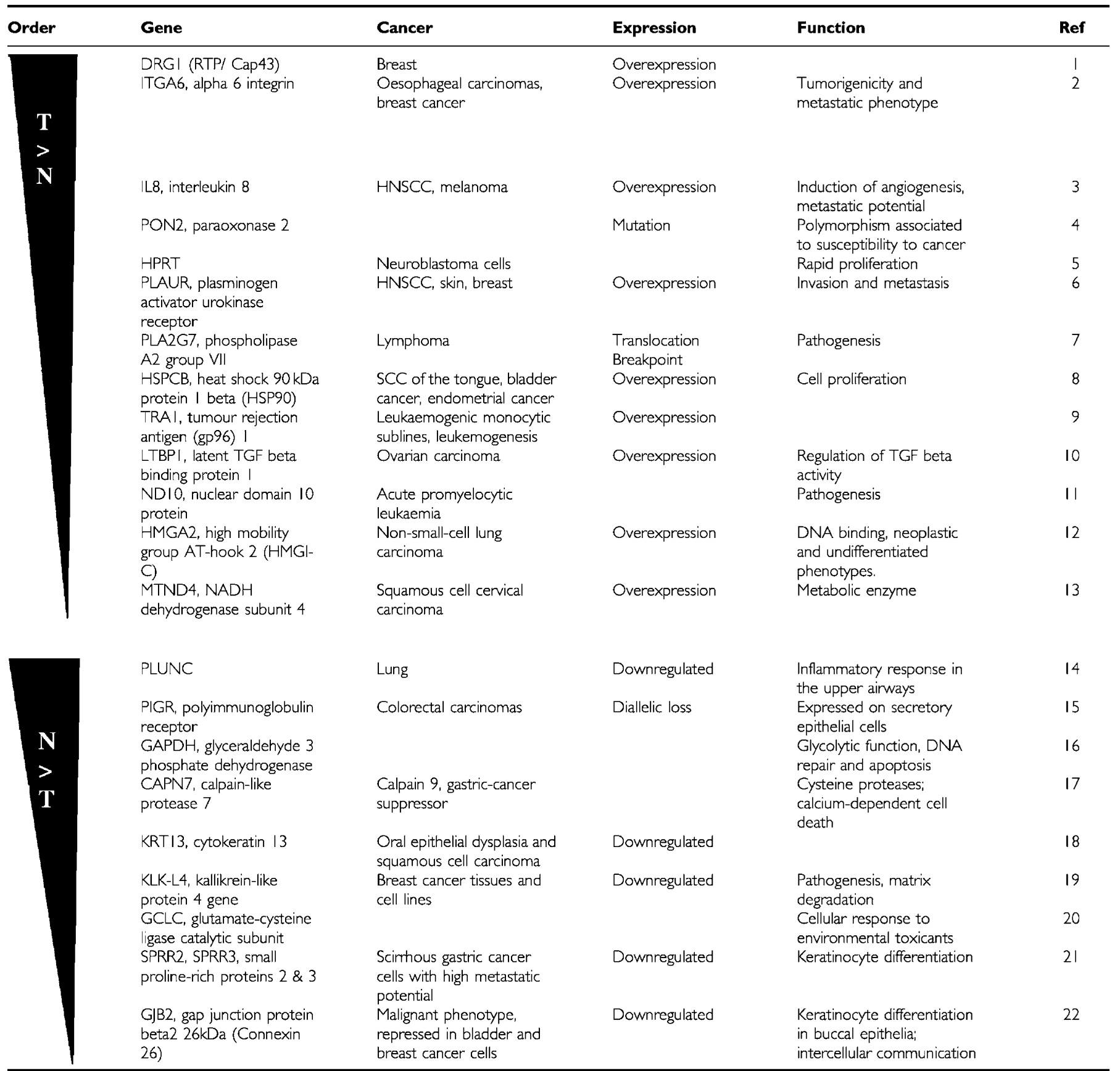

The genes identified in this study that have been described to be implicated other human cancers are listed, with their expression pattern in our study $(T>N$ or $N>T)$, their names, the other cancers concerned, the reported alterations (expression), their functions and references (Ref).References: $I=$ Cangul et al (2002); $2=$ Mukhopadhyay et al (1999), Tanaka et al (2000); 3 =Bar-Eli (1999), Kawano et ol (200 I), Liss et ol (200I); $4=$ Hegele (1999); $5=$ Connolly et al (200I); $6=$ Mazar (200I), Romer et of (200I) Schmidt and Grunsfelder (200I), van der Pluijm et al (200I); 7 = Lecointe et al (1999); 8 = Cardillo et al (2000), Ito et al (1998), Wataba et al (2001); $9=$ Kasukabe et al (1997) $10=$ Higashi et al (200 I); | I =Sternsdorf et al (1997); 12 = Manfioletti et al (|99|), Rogalla et al (1998); |3=Cheng et al (2002); |4=Bingle and Bingle (2000); | $5=$ Krajci et a (1996); 16 = Sirover (1999); 17 = Yoshikawa et al (2000); 18=Bloor et al (200I); $19=$ Yousef et al (2000); 20 =Walsh et al (2001); $21=$ Hippo et al (200 I); $22=$ Grossman et al (1994), Lucke et al (1999), Singal et al (2000).

(Figures 4A, 5A, and 6A). The differences in expression, measured by RT-QPCR, were at least two-fold in at least half of the tumours for seven of the eight genes analysed. DRG1, APOL2, HSCPC150, and PSMB8, and the novel sequence clone RPI-68D18 are overexpressed in nine, eight, 12, eight, and six patients, respectively. Overall, the expression profiles correlate well with the behaviour observed at the DD band level.

\section{DISCUSSION}

We have compared the expression profiles of hypopharyngeal tumours with matched normal tissues by the PCR-DD. This study of a specific site of HNSCC provides a novel collection of cancerrelated genes. Our results are of high quality since the DD sequences were reselected with several rounds of reverse North- 
erns, and there was a consistent correlation between the DD profiles and analyses by classical Northerns, virtual Northerns, and RT-QPCR. The sequences reported here had a consistent DD profile across the tumour samples, whereas other bands (about $20 \%$ ) with tumour stage-specific profiles need to be studied further with a larger number of tumours. Only eight out of 70 genes overlap between our and other profiles of HNSCC (Leethanakul et al, 2000; Alevizos et al, 2001; Al Moustafa et al, 2002; Belbin et al, 2002; El-Naggar et al, 2002; Mendez et al, 2002; Xie et al, 2000), possibly because, in contrast to these other studies, we did not restrict the profiling to particular genes on arrays, since PCR-DD samples the whole transcriptome. Moreover, we restricted our analysis to a very specific site. Six of the common genes are expressed in the same manner (ITGA6, PON2, STAT1, KRT13, SPR2, and EMP1). In contrast to these studies, we found that GJB2 is underexpressed in tumours and DRG1 is overexpressed. In our experiments, DRG1 was shown to be overexpressed by four techniques (DD-PCR, reverse Northerns, classical Northerns, and RT-QPCR). Furthermore, DRG1 has been shown to be overexpressed in other tumours (see Cangul et al, 2002). There is some overlap between our list and profiles of other cancers (see Table 4), which potentially identifies genes with general functions in cancer.

The genes we have identified have a biased chromosomal distribution, with many located at $12 \mathrm{p} 12-13$ and $1 \mathrm{q} 21-22$ (Table 3). Out of 70 genes, six localise to 12p12-13 (A2M, GAPDH, LPRP, CLECSF2, PRH, and EMP1), and three to 1q21-22 (SPRR3, SPRR2, and S100A9). These are the two most frequently altered regions in nasopharyngeal carcinoma (Marenholz et al, 1996; Chen et al, 1999; Salomon-Nguyen et al, 2000; Sato et al, 2001), indicating that transformation has complex effects on epidermoid cell biology.

We identified sequences that might be expressed in non epidermoid cells in the tumours, including endothelial-specific and immune-related genes. EFNB2, which is overexpressed in tumours, is a trans-membrane ligand specifically expressed in arterial endothelial cells (Gale et al, 2001). Of the 57 known genes, 16 are immune related (Table 3), and, in particular, the nine that are overexpressed could be considered as potential circulating markers for diagnostic purposes. Certain of the immune-related genes have also been associated with epithelial tissue differentiation and growth control, including PLUNC (Iwao et al, 2001), PIGR (Nihei et al, 1996), Statl (Maziere et al, 2000), and HSPCB (Edwards et al, 1991), PLAUR (Chapman and Wei, 2001; Ahmed et al, 2002) and PLA2G7 (Tao et al, 1996). In particular, PLAUR is a pan T cell activating antigen that has also been associated with epithelial-derived tumour development. It interacts with integrins to regulate cell-matrix interactions (Chapman and Wei, 2001; Ahmed et al, 2002). PLAUR and PLA2G7 are linked, as PLAUR is activated by PAF, which in turn is a substrate of PLA2G7 (Tao et al, 1996).

Some of the differentially expressed genes are involved in detoxification pathways and cellular defences against insults. Physiological response to environmental insult from tobacco and alcohol is particularly important in HNSCC (Johnson, 2001) and the differential expression of xenobiotic and detoxification enzymes has been reported in other transcriptome level studies (Alevizos et al, 2001). We identified two genes involved in antioxidation, GCLC (Talalay, 2000) and PON2 (Ng et al, 2001), and another involved in the response to oxidative damage to DNA, TDG (Laval, 1996). Cellular defences against insults could also account for the overexpression of heat shock and stress proteins, such as HSPCB, TRA1 (Maki et al, 1990) and DRG1 (Agarwala et al, 2000).

Cell-surface receptors, membrane-associated proteins and enzymes that are overexpressed in tumours are potential tumour markers and targets for drug design (Nam and Parang, 2003). We identified four overexpressed cell surface and membrane associated proteins (ITGA6, GJB2, PLAUR, and EFNB2) and nine enzymes (PON2, HPRT, HSCP150, APOBEC3, PLA2G7, HSPCB, MTND4, DIA1, and TDG). Interestingly, inhibitors of HSPCB are currently being tested in clinical trials (Neckers, 2002).

The major strength of the PCR-DD is to identify unknown genes from limiting amounts of biological material. We identified 13 differentially expressed sequences that exist only in the EST, theoretical cDNA or hypothetical protein databases, or correspond to chromosomal locations. One of these, clone RPI-68D18, was confirmed to be overexpressed in tumours by RT-QPCR. This sequence is homologous to a number of ESTs but otherwise has no significant relationship to cDNAs or proteins in the GENEMBL databases. The differences in expression we report provide insights into the biology of HNSCC and subjects for further study. The gene products that are expressed on the cell surface or have enzymatic activity are particularly noteworthy, since successful therapeutics have been developed against these types of molecules. Finally, the novel sequences may open totally new avenues for further research and development of new therapeutics and markers.

\section{ACKNOWLEDGEMENTS}

We would like to thank: (a) Annaïck Carles, Raymond Ripp and Olivier Poch for help with the bioinformatics; (b) the IGBMC core facilities for help and support; (c) the Fondation pour la Recherche Médicale for a fellowship for JY; (d) the Ligue Régionale (BasRhin/Haut-Rhin) contre le Cancer for funding for an RT-QPCR machine; and (e) ARERS Verre Espoir (No. 138.02), Aventis, the Centre National de la Recherche Scientifique, the Institut National de la Santé et de la Recherche Médicale, the Hôpital Universitaire de Strasbourg, the Association pour la Recherche sur le Cancer, the Fondation pour la Recherche Médicale, the Ligue Nationale Française contre le Cancer (Equipe labellisée), the Ligue Régionale (Haut-Rhin) contre le Cancer, the Ligue Régionale (Bas-Rhin) contre le Cancer, the European Union (FP5 Project QLK6-200000159) and the Ministère de la Recherche (Décisions 99H0161 and 98C0372) for financial assistance.

\section{REFERENCES}

Agarwala KL, Kokame K, Kato H, Miyata T (2000) Phosphorylation of RTP, an ER stress-responsive cytoplasmic protein. Biochem Biophys Res Commun 272: $641-647$

Ahmed N, Pansino F, Clyde R, Murthi P, Quinn MA, Rice GE, Agrez MV, Mok S, Baker MS (2002) Overexpression of alpha(v)beta6 integrin in serous epithelial ovarian cancer regulates extracellular matrix degradation via the plasminogen activation cascade. Carcinogenesis 23: 237-244

Al Moustafa AE, Alaoui-Jamali MA, Batist G, Hernandez-Perez M, Serruya C, Alpert L, Black MJ, Sladek R, Foulkes WD (2002) Identification of genes associated with head and neck carcinogenesis by cDNA microarray comparison between matched primary normal epithelial and squamous carcinoma cells. Oncogene 21: 2634-2640

Alevizos I, Mahadevappa M, Zhang X, Ohyama H, Kohno Y, Posner M, Gallagher GT, Varvares M, Cohen D, Kim D, Kent R, Donoff RB, Todd R, Yung CM, Warrington JA, Wong DT (2001) Oral cancer in vivo gene expression profiling assisted by laser capture microdissection and microarray analysis. Oncogene 20: 6196-6204

Bar-Eli M (1999) Role of interleukin-8 in tumor growth and metastasis of human melanoma. Pathobiology 67: 12-18

Belbin TJ, SB, Barber I, Socci N, Wenig B, Smith R, Prystowsky MB, Childs G (2002) Molecular classification of head and neck squamous cell carcinoma using cDNA microarrays. Cancer Res 62: 1184-1190

Bingle CD, Bingle L (2000) Characterisation of the human plunc gene, a gene product with an upper airways and nasopharyngeal 
restricted expression pattern. Biochim Biophys Acta 1493: $363-367$

Bloor BK, Seddon SV, Morgan PR (2001) Gene expression of differentiation-specific keratins in oral epithelial dysplasia and squamous cell carcinoma. Oral Oncol 37: 251-261

Cangul H, Salnikow K, Yee H, Zagzag D, Commes T, Costa M (2002) Enhanced expression of a novel protein in human cancer cells: a potential aid to cancer diagnosis. Cell Biol Toxicol 18: 87-96

Cardillo MR, Sale P, Di Silverio F (2000) Heat shock protein-90, IL-6 and IL-10 in bladder cancer. Anticancer Res 20: 4579-4583

Chapman HA, Wei Y (2001) Protease crosstalk with integrins: the urokinase receptor paradigm. Thromb Haemost 86: 124-129

Chen YJ, Ko JY, Chen PJ, Shu CH, Hsu MT, Tsai SF, Lin CH (1999) Chromosomal aberrations in nasopharyngeal carcinoma analyzed by comparative genomic hybridization. Genes Chromosomes Cancer 25: $169-175$

Cheng Q, Lau WM, Tay SK, Chew SH, Ho TH, Hui KM (2002) Identification and characterization of genes involved in the carcinogenesis of human squamous cell cervical carcinoma. Int J Cancer 98: 419-426

Connolly GP, Duley JA, Stacey NC (2001) Abnormal development of hypoxanthine-guanine phosphoribosyltransferase-deficient CNS neuroblastoma. Brain Res 918: $20-27$

Coussens LM, Raymond WW, Bergers G, Laig-Webster M, Behrendtsen O, Werb Z, Caughey GH, Hanahan D (1999) Inflammatory mast cells upregulate angiogenesis during squamous epithelial carcinogenesis. Genes Dev 13: 1382 - 1397

Dimery IW, Hong WK (1993) Overview of combined modality therapies for head and neck cancer. J Natl Cancer Inst 85: 95-111

Edwards MJ, Marks R, Dykes PJ, Merrett VR, Morgan HE, O’Donovan MR (1991) Heat shock proteins in cultured human keratinocytes and fibroblasts. J Invest Dermatol 96: 392-396

El-Naggar AK, Kim HW, Clayman GL, Coombes MM, Le B, Lai S, Zhan F, Luna MA, Hong WK, Lee JJ (2002) Differential expression profiling of head and neck squamous carcinoma: significance in their phenotypic and biological classification. Oncogene 21: 8206-8219

Franz O, Bruchhaus II, Roeder T (1999) Verification of differential gene transcription using virtual Northern blotting. Nucleic Acids Res 27: e3

Gale NW, Baluk P, Pan L, Kwan M, Holash J, DeChiara TM, McDonald DM, Yancopoulos GD (2001) Ephrin-B2 selectively marks arterial vessels and neovascularization sites in the adult, with expression in both endothelial and smooth muscle cells. Dev Biol 230: $151-160$

Genden EM, Ferlito A, Bradley PJ, Rinaldo A, Scully C (2003) Neck disease and distant metastases. Oral Oncol 39: 207-212

Glynne-Jones E, Harper ME, Seery LT, James R, Anglin I, Morgan HE, Taylor KM, Gee JM, Nicholson RI (2001) TENB2, a proteoglycan identified in prostate cancer that is associated with disease progression and androgen independence. Int J Cancer 94: 178-184

Grossman HB, Liebert M, Lee IW, Lee SW (1994) Decreased connexin expression and intercellular communication in human bladder cancer cells. Cancer Res 54: $3062-3065$

Hegele RA (1999) Paraoxonase genes and disease. Ann Med 31: 217-224

Higashi T, Sasagawa T, Inoue M, Oka R, Shuangying L, Saijoh K (2001) Overexpression of latent transforming growth factor-beta 1 (TGF-beta 1) binding protein 1 (LTBP-1) in association with TGF-beta 1 in ovarian carcinoma. Jpn J Cancer Res 92: 506-515

Hippo Y, Yashiro M, Ishii M, Taniguchi H, Tsutsumi S, Hirakawa K, Kodama T, Aburatani H (2001) Differential gene expression profiles of scirrhous gastric cancer cells with high metastatic potential to peritoneum or lymph nodes. Cancer Res 61: 889-895

Ito T, Kawabe R, Kurasono Y, Hara M, Kitamura H, Fujita K, Kanisawa M (1998) Expression of heat shock proteins in squamous cell carcinoma of the tongue: an immunohistochemical study. J Oral Pathol Med 27: 18-22

Iwao K, Watanabe T, Fujiwara Y, Takami K, Kodama K, Higashiyama M, Yokouchi H, Ozaki K, Monden M, Tanigami A (2001) Isolation of a novel human lung-specific gene, LUNX, a potential molecular marker for detection of micrometastasis in non-small-cell lung cancer. Int J Cancer 91: $433-437$

Johnson N (2001) Tobacco use and oral cancer: a global perspective. J Dent Educ 65: 328 - 339

Kasukabe T, Okabe-Kado J, Honma Y (1997) TRA1, a novel mRNA highly expressed in leukemogenic mouse monocytic sublines but not in nonleukemogenic sublines. Blood 89: 2975-2985

Kawano T, Yanoma S, Nishimura G, Tsukuda M (2001) The inhibitory effects of TNP470 on tumour growth of head and neck carcinoma cell producing interleukin-8. J Laryngol Otol 115: 802-807
Krajci P, Meling GI, Andersen SN, Hofstad B, Vatn MH, Rognum TO, Brandtzaeg P (1996) Secretory component mRNA and protein expression in colorectal adenomas and carcinomas. Br J Cancer 73: 1503-1510

Laval J (1996) Role of DNA repair enzymes in the cellular resistance to oxidative stress. Pathol Biol (Paris) 44: 14-24

Lecointe N, Meerabux J, Ebihara M, Hill A, Young BD (1999) Molecular analysis of an unstable genomic region at chromosome band $11 \mathrm{q} 23$ reveals a disruption of the gene encoding the alpha2 subunit of plateletactivating factor acetylhydrolase (Pafah1a2) in human lymphoma. Oncogene 18: $2852-2859$

Leethanakul C, Patel V, Gillespie J, Pallente M, Ensley JF, Koontongkaew S, Liotta LA, Emmert-Buck M, Gutkind JS (2000) Distinct pattern of expression of differentiation and growth-related genes in squamous cell carcinomas of the head and neck revealed by the use of laser capture microdissection and cDNA arrays. Oncogene 19: 3220-3224

Leon X, Ferlito A, Myer III CM, Saffiotti U, Shaha AR, Bradley PJ, Brandwein MS, Anniko M, Elluru RG, Rinaldo A (2002) Second primary tumors in head and neck cancer patients. Acta Otolaryngol 122: $765-778$

Leonard JH, Kearsley JH, Chenevix-Trench G, Hayward NK (1991) Analysis of gene amplification in head-and-neck squamous-cell carcinoma. Int $J$ Cancer 48: $511-515$

Liang P (1998) Factors ensuring successful use of differential display. Methods 16: $361-364$

Liss C, Fekete MJ, Hasina R, Lam CD, Lingen MW (2001) Paracrine angiogenic loop between head-and-neck squamous-cell carcinomas and macrophages. Int J Cancer 93: 781-785

Lucke T, Choudhry R, Thom R, Selmer IS, Burden AD, Hodgins MB (1999) Upregulation of connexin 26 is a feature of keratinocyte differentiation in hyperproliferative epidermis, vaginal epithelium, and buccal epithelium. J Invest Dermatol 112: $354-361$

Maki RG, Old LJ, Srivastava PK (1990) Human homologue of murine tumor rejection antigen gp96: 5'-regulatory and coding regions and relationship to stress-induced proteins. Proc Natl Acad Sci USA 87: $5658-5662$

Manfioletti G, Giancotti V, Bandiera A, Buratti E, Sautiere P, Cary P, CraneRobinson C, Coles B, Goodwin GH (1991) cDNA cloning of the HMGI-C phosphoprotein, a nuclear protein associated with neoplastic and undifferentiated phenotypes. Nucleic Acids Res 19: 6793-6797

Marenholz I, Volz A, Ziegler A, Davies A, Ragoussis I, Korge BP, Mischke D (1996) Genetic analysis of the epidermal differentiation complex (EDC) on human chromosome 1q21: chromosomal orientation, new markers, and a 6-Mb YAC contig. Genomics 37: 295-302

Mazar AP (2001) The urokinase plasminogen activator receptor (UPAR) as a target for the diagnosis and therapy of cancer. Anticancer Drugs 12: $387-400$

Maziere C, Dantin F, Dubois F, Santus R, Maziere J (2000) Biphasic effect of UVA radiation on STAT1 activity and tyrosine phosphorylation in cultured human keratinocytes. Free Radic Biol Med 28: 1430-1437

Mendez E, Cheng C, Farwell DG, Ricks S, Agoff SN, Futran ND, Weymuller Jr EA, Maronian NC, Zhao LP, Chen C (2002) Transcriptional expression profiles of oral squamous cell carcinomas. Cancer 95: $1482-1494$

Mukhopadhyay R, Theriault RL, Price JE (1999) Increased levels of alpha6 integrins are associated with the metastatic phenotype of human breast cancer cells. Clin Exp Metast 17: 325-332

Nam NH, Parang K (2003) Current targets for anticancer drug discovery. Curr Drug Targets 4: 159-179

Neckers L (2002) Hsp90 inhibitors as novel cancer chemotherapeutic agents. Trends Mol Med 8: S55-61

Nelson AR, Fingleton B, Rothenberg ML, Matrisian LM (2000) Matrix metalloproteinases: biologic activity and clinical implications. J Clin Oncol 18: $1135-1149$

Ng CJ, Wadleigh DJ, Gangopadhyay A, Hama S, Grijalva VR, Navab M, Fogelman AM, Reddy ST (2001) Paraoxonase-2 is a ubiquitously expressed protein with antioxidant properties and is capable of preventing cell-mediated oxidative modification of low density lipoprotein. J Biol Chem 276: 44444-44449

Nihei Y, Maruyama K, Endo Y, Sato T, Kobayashi K, Kaneko F (1996) Secretory component (polymeric immunoglobulin receptor) expression on human keratinocytes by stimulation with interferon-gamma and differences in response. J Dermatol Sci 11: 214-222

Rogalla P, Drechsler K, Schroder-Babo W, Eberhardt K, Bullerdiek J (1998) HMGIC expression patterns in non-small lung cancer and surrounding tissue. Anticancer Res 18: $3327-3330$ 
Romer J, Pyke C, Lund LR, Ralfkiaer E, Dano K (2001) Cancer cell expression of urokinase-type plasminogen activator receptor mRNA in squamous cell carcinomas of the skin. I Invest Dermatol 116: $353-358$

Salomon-Nguyen F, Della-Valle V, Mauchauffe M, Busson-Le Coniat M, Ghysdael J, Berger R, Bernard OA (2000) The $t(1 ; 12)(q 21 ; p 13)$ translocation of human acute myeloblastic leukemia results in a TELARNT fusion. Proc Natl Acad Sci USA 97: 6757-6762

Sankaranarayanan R, Masuyer E, Swaminathan R, Ferlay J, Whelan S (1998) Head and neck cancer: a global perspective on epidemiology and prognosis. Anticancer Res 18: $4779-4786$

Sasaki H, Chen LB, Auclair D, Moriyama S, Kaji M, Fukai I, Kiriyama M, Yamakawa Y, Fujii Y (2001) Overexpression of Hrad17 gene in non-small cell lung cancers correlated with lymph node metastasis. Lung Cancer 34: $47-52$

Sato Y, Kobayashi H, Suto Y, Olney HJ, Davis EM, Super HG, Espinosa III R, Le Beau MM, Rowley JD (2001) Chromosomal instability in chromosome band 12p13: multiple breaks leading to complex rearrangements including cytogenetically undetectable sub-clones. Leukemia 15: $1193-1202$

Schmidt M, Grunsfelder P (2001) Urokinase-type plasminogen activator expression and proliferation stimulation in head and neck squamous cell carcinoma in vitro and in situ. Arch Otolaryngol Head Neck Surg 127: $679-682$

Scully C, Field JK, Tanzawa H (2000) Genetic aberrations in oral or head and neck squamous cell carcinoma 2: chromosomal aberrations. Oral Oncol 36: $311-327$

Singal R, Tu ZJ, Vanwert JM, Ginder GD, Kiang DT (2000) Modulation of the connexin26 tumor suppressor gene expression through methylation in human mammary epithelial cell lines. Anticancer Res 20: $59-64$

Sirover MA (1999) New insights into an old protein: the functional diversity of mammalian glyceraldehyde-3-phosphate dehydrogenase. Biochim Biophys Acta 1432: $159-184$

Sobin LH, Wittekind C (1997) TNM Classification of Malignant Tumors. New York: Wiley-Liss, Inc.

St Croix B, Rago C, Velculescu V, Traverso G, Romans KE, Montgomery E, Lal A, Riggins GJ, Lengauer C, Vogelstein B, Kinzler KW (2000) Genes expressed in human tumor endothelium. Science 289: 1197-1202

Sternsdorf T, Jensen K, Zuchner D, Will H (1997) Cellular localization, expression, and structure of the nuclear dot protein 52. J Cell Biol 138: $435-448$
Talalay P (2000) Chemoprotection against cancer by induction of phase 2 enzymes. Biofactors 12: 5-11

Tanaka Y, Mimori K, Shiraishi T, Ohkura Y, Takubo K, Mafune K, Barnard GF, Mori M (2000) alpha6 Integrin expression in esophageal carcinoma. Int J Oncol 16: 725-729

Tao Y, Bazan HE, Bazan NG (1996) Platelet-activating factor enhances urokinase-type plasminogen activator gene expression in corneal epithelium. Invest Ophthalmol Vis Sci 37: 2037-2046

Trenkle T, Welsh J, McClelland M (1999) Differential display probes for cDNA arrays. Biotechniques 27: 554-560, 562, 564

van den Hooff A (1988) Stromal involvement in malignant growth. Adv Cancer Res 50: 159-196

van der Pluijm G, Sijmons B, Vloedgraven H, van der Bent C, Drijfhout JW, Verheijen J, Quax P, Karperien M, Papapoulos S, Lowik C (2001) Urokinase-receptor/integrin complexes are functionally involved in adhesion and progression of human breast cancer in vivo. Am J Pathol 159: 971 - 982

Walsh AC, Feulner JA, Reilly A (2001) Evidence for functionally significant polymorphism of human glutamate cysteine ligase catalytic subunit: association with glutathione levels and drug resistance in the National Cancer Institute tumor cell line panel. Toxicol Sci 61: 218-223

Wataba K, Saito T, Fukunaka K, Ashihara K, Nishimura M, Kudo R (2001) Over-expression of heat shock proteins in carcinogenic endometrium. Int J Cancer 91: $448-456$

Xie L, Xu L, He Z, Zhou W, Wang L, Zhang L, Lan K, Ren C, Liu W, Yao K (2000) Identification of differentially expressed genes in nasopharyngeal carcinoma by means of the Atlas human cancer cDNA expression array. $J$ Cancer Res Clin Oncol 126: 400 - 406

Ying $\mathrm{H}, \mathrm{Yu}$ Y, Xu Y (2001) Cloning and characterization of F-LANa, upregulated in human liver cancer. Biochem Biophys Res Commun 286: $394-400$

Yoshikawa Y, Mukai H, Hino F, Asada K, Kato I (2000) Isolation of two novel genes, down-regulated in gastric cancer. Jpn J Cancer Res 91: $459-463$

Yousef GM, Chang A, Diamandis EP (2000) Identification and characterization of KLK-L4, a new kallikrein-like gene that appears to be down-regulated in breast cancer tissues. J Biol Chem 275: $11891-11898$

Zhang H, Zhang R, Liang P (1997) Differential screening of differential display cDNA products by reverse Northern. Methods Mol Biol 85: $87-93$ 